\title{
PORTUGUESE STUDIES
}

Volume 31 Number 2 2015

\author{
In Medieval Mode: \\ Collected Essays in Honour of \\ Stephen Parkinson on his Retirement
}

\author{
Founding Editor \\ Helder Macedo \\ Guest Editors \\ Cláudia Pazos Alonso \\ Claire Williams \\ Editors \\ Francisco Bethencourt \\ Paulo de Medeiros \\ Paul Melo e Castro \\ Hilary OWen \\ Juliet Perkins \\ LÚCIA SÁ \\ Claire Williams \\ Editorial Assistant \\ RICHARD CORRELL \\ Production Editor \\ Graham Nelson
}

MODERN HUMANITIES RESEARCH ASSOCIATION 


\section{PORTUGUESE STUDIES}

A peer-reviewed biannual multi-disciplinary journal devoted to research on the cultures, literatures, history and societies of the Lusophone world

\begin{tabular}{cl}
\multicolumn{2}{c}{ International Advisory Board } \\
David Brookshaw & Maria Manuel lisboa \\
João de Pina Cabral & Kenneth Maxwell \\
Ivo José De Castro & Laura de Mello e Souza \\
Thomas F. Earle & Maria Irene Ramalho \\
John Gledson & Silviano Santiago \\
ANNa Klobucka &
\end{tabular}

Portuguese Studies and other journals published by the MHRA may be ordered from JSTOR (http://about.jstor.org/csp).

The Modern Humanities Research Association was founded in Cambridge in 1918 and has become an international organization with members in all parts of the world. It is a registered charity number 1064670, and a company limited by guarantee, registered in England number 3446016. Its main object is to encourage advanced study and research in modern and medieval European languages, literatures, and cultures by its publication of journals, book series, and its Style Guide. Further information about the activities of the Association and individual membership may be obtained from the Membership Secretary, Dr Jessica Goodman, Clare College, Trinity Lane, Cambridge Св2 1TL, UK, email membership@mhra.org.uk, or from the website at: www.mhra.org.uk

Disclaimer: Statements of fact and opinion in the content of Portuguese Studies are those of the respective authors and contributors and not of the journal editors or of the Modern Humanities Research Association (MHRA). MHRA makes no representation, express or implied, in respect of the accuracy of the material in this journal and cannot accept any legal responsibility or liability for any errors or omissions that may be made.

Parts of this work may be reproduced as permitted under legal provisions for fair dealing (or fair use) for the purposes of research, private study, criticism, or review, or when a relevant collective licensing agreement is in place. All other reproduction requires the written permission of the copyright holder who may be contacted at rights@mhra.org.uk.

$$
\begin{gathered}
\text { ISSN 0267-5315 (print) ISSN 2222-4270 (online) } \\
\text { ISBN } 978-1-78188-210-8
\end{gathered}
$$

(C) 2015 The Modern Humanities Research Association Salisbury House, Station Road, Cambridge CB1 2LA, United Kingdom 


\section{Portuguese Studies vol. 31 NO. 2 In Medieval Mode: \\ Collected Essays in Honour of \\ Stephen Parkinson on his Retirement}

\section{CONTENTS}

$\begin{array}{ll}\text { Preface } & 147\end{array}$

Introduction $\quad 148$

Cláudia Pazos Alonso and Claire Williams

Sanctity and Social Alienation in Twelfth-Century Braga as

Portrayed in the Vita Sancti Geraldi

STEPHEN LAY

Seeing is Believing: The Miniatures in the Cantigas de Santa Maria and Medieval Devotional Practices

KiRstin Kennedy

Early Modern Marginalia in the Cancioneiro da Ajuda

André B. Penafiel

The Manuscript Tradition of the Regula Benedicti in Portuguese 195 Ivo Castro

Service, not Subservience: Chapter 98 of Dom Duarte's

Leal Conselheiro

Juliet Perkins

Rui de Pina, Crónica de D. Afonso V and Bodleian MS Don. c. 230 222

T. F. EARLE

Damião de Góis's Livro de Linhagens: An Untold (Hi)Story

Catarina Barceló Fouto

Lusophone Studies: A Cumulative Area Bibliography, 2013-15

250

Compiled by Emilce Rees

Abstracts 
Seeing is Believing: The Miniatures in the Cantigas de Santa Maria and Medieval Devotional Practices

Kirstin Kennedy

Aвstract. The miniatures that accompany the Cantigas de Santa Maria have been examined in terms of their content, relationship to the text, method of creation and political and religious ideology. In this article I refer to recent research about the medieval practice of Christian devotion to draw out some of the doctrinal messages inherent in the miniatures, messages that have previously been overlooked in favour of stylistic, narrative or archaeological interpretations. I will argue that the miniatures reflect contemporary ideas about the physical effect of vision, and that they illustrate fundamental arguments of Christian theology with reference to the sense of sight.

Keywords. Alfonso X, Cantigas de Santa Maria, Christian church, Middle Ages, material culture - religious aspects, miracles - Europe, reliquaries, Virgin Mary, five senses.

Resumo. As miniaturas que acompanham as Cantigas de Santa Maria já foram analisadas em termos de conteúdo, da sua relação com o texto, do método de criação e da sua ideologia política e religiosa. No presente artigo baseio-me em pesquisas recentes sobre a prática medieval de devoção cristã no intuito de extrair algumas das mensagens doutrinárias inerentes às miniaturas, que têm sido negligenciadas no passado em favor de interpretações estilísticas, narrativas ou arqueológicas. Avanço que as miniaturas refletem ideias contemporâneas sobre o efeito físico da visão, e que ilustram argumentos fundamentais da teologia cristã com referência ao sentido da visão.

Palavras-chave. Alfonso X, Cantigas de Santa Maria, igreja cristã, Idade Média, cultura material - aspetos religiosos, milagres - Europa, relicários, Virgem Maria, cinco sentidos.

Early Modern Marginalia in the Cancioneiro da Ajuda André B. PenAfiel

Abstract. The history of literary reception, within Galician-Portuguese scholarship, remains a relatively unexplored field, largely due to the scarcity of sources. On the other hand, codicological studies tend to privilege the original features of a given manuscript over later additions. The present article, instead, focuses on the late medieval and early-modern marginalia to be found in the thirteenth-century, Iberian manuscript, the Cancioneiro da Ajuda. It includes a comprehensive catalogue and edition of these notes, presented in a partially modernized spelling, accompanied by a short study. It is hoped that both will pave the way for future studies on literary reception that could make use of textual evidence available but so far little explored.

Keywords. Cancioneiro da Ajuda, marginalia, edition, literary reception. 
Resumo. Estudos de recepção literária da lírica galego-portuguesa ainda são raros, em grande parte devido à escassez de fontes históricas. Ao mesmo tempo, estudos codicológicos tendem a valorizar os elementos originais dos manuscritos em detrimento de acréscimos posteriores. $\mathrm{O}$ presente artigo concentra-se em anotações marginais encontradas no Cancioneiro da Ajuda, manuscrito do século XIII, e datáveis do fim do período medieval ou início da Idade Moderna. Além de breve estudo, incluiu-se um catálogo destas anotações que se pretende exaustivo, devidamente editadas em grafia parcialmente modernizada. Esperase que tanto a edição como a análise revelem-se instrumentos úteis para estudos futuros sobre recepção literária que poderão assim fazer uso destes elementos até agora pouco explorados.

Palavras-Chave. Cancioneiro da Ajuda, marginalia, edição, recepção literária.

\section{The Manuscript Tradition of the Regula Benedicti in Portuguese Ivo Castro}

Aвstract. The Regula Benedicti [Rule of St. Benedict] in Portugal in the Middle Ages is notable for the number of translations done of it and for the number of manuscripts which still survive. Today, almost all of these manuscripts have been edited and ordered chronologically, making it possible to identify and group the relevant translations and, by comparing the different versions, to establish a timeline of the diachronic evolution of the Portuguese language.

Keywords. Old Portuguese, medieval manuscripts, translation, Rule of St Benedict.

Resumo. A transmissão da Regula Benedicti na Idade Média portuguesa é notável pela quantidade de traduções feitas e pela quantidade de manuscritos que ainda sobrevivem. Hoje estão editados praticamente todos esses manuscritos e ordenados cronologicamente; torna-se possível identificar o agrupamento das traduções e, comparando versões, estabelecer uma diacronia real da evolução da língua portuguesa.

Palavras-chave. Português medieval, manuscritos medievais, tradução, Regula Benedicti.

Service, not Subservience: Chapter 98 of D. Duarte's Leal Conselheiro Juliet Perkins

Aвstract. Chapter 98 of the king D. Duarte's moral treatise, Leal Conselheiro, recounts the good relations enjoyed by him and his siblings with their father, D. João I. When detached from the overall context, it reads as a somewhat rosy portrait of family harmony, appropriate to a panegyric of the Avis dynasty. However, when read within the coherent moral framework of the treatise, the chapter reveals a quasi-monastical striving towards obedience, humility and service on the part of D. Duarte, which may be traced in large part to 


\title{
Early Modern Marginalia in the Cancioneiro da Ajuda
}

\author{
ANDré B. PenAfiel
}

University of Oxford

\section{Introduction}

The Cancioneiro da Ajuda features over sixty comments by early modern readers on its pages but they have received almost no studies of their own. In the early twentieth century, Michaëlis transcribed most of the marginalia in her first volume of the Cancioneiro da Ajuda, though they were scattered throughout the book, as footnotes to individual poems. In the second volume, after stating that, within the Cancioneiro's marginalia, the later inscriptions are the ones that have 'maior interesse' [greater interest], one finds a four-page study with further transcriptions and corrections to the first volume. ${ }^{1} \mathrm{~A}$ few decades later, Carter, in the second appendix to his edition, includes a list of the marginalia and their locations, with only a few omissions and mistakes. ${ }^{2} \mathrm{He}$ does not, however, provide any information on the hand of each note, and those added by later readers are not distinguished from those written by medieval revisers working in the original scriptorium, whose correction notes were not erased. Also, a slight inconvenience is the fact that they are referred to by page, rather than folio numbers.

Yet the most important contribution to the study of the Cancioneiro da Ajuda's marginalia came in 2004, with Susana Pedro's Análise Paleográfica das anotações marginais e finais no Cancioneiro da Ajuda. Pedro's work has the merit of reproducing diplomatically most of the notes, while systematizing and enhancing both Michaëlis's and Carter's work. That is to say that Michaëlis is comprehensive, but the way in which she presents information makes it difficult to build an overall picture; Carter edits all the marginalia in a single place, but his edition lacks crucial information which would render it more useful. Pedro is comprehensive, structures her edition intelligently and corrects a number of mistakes found in the two previous editions, even if her focus is decisively palaeographical and codicological, and this means that her main concern is not the early modern marginalia or its potential for studies on literary reception.

\footnotetext{
1 Carolina Michaëlis de Vasconcellos, Cancioneiro da Ajuda, 2 vols (Halle: Max Niemeyer, 1904), II, $67 ; 175-78$.

Henry H. Carter, Cancioneiro da Ajuda: A Diplomatic Edition (New York: Modern Language Association of America; London: Oxford University Press, 1941).
}

Portuguese Studies vol. 31 no. 2 (2015), 183-94

(c) Modern Humanities Research Association 2015 
Finally, Maria Ana Ramos's study Invoco el rrey Dom Denis deserves mentioning, even if its relevance for literary reception research is not immediately obvious. Based on two notes, Ramos argued that the manuscript once belonged to Pedro Homem, a fifteenth-century poet connected to the Portuguese royal house. Thus, her theory connects the Galician-Portuguese lyric with the Portuguese aristocracy of the time of the Cancioneiro Geral. ${ }^{3}$ Its relevance to the present study lies in the suggestion that the marginalia here analysed are contemporary to a specific group of poets, allowing us to see points of contact between thirteenth- and fifteenth-century aesthetics.

\section{This Edition}

The present study transcribes, in the Appendix to this article, every piece of late medieval or early modern marginalia in a single place for the first time. Based on the concept of campo bibliográfico ${ }^{4}$ a modernizing transcription has been preferred, since Pedro's work is accessible and provides an authoritative diplomatic transcription. By modernized, we mean:

(1) special characters, like long-s and $r$-rotunda, are standardized, though $i, j$, $y, u, v$ and tils are employed according to the original spelling;

(2) fragmented words are completed whenever possible;

(3) abbreviated words are expanded;

(4) words are separated and hyphenized according to modern usage.

Due to this article's scope, the earliest marginalia, made at the time of the manuscript production by scribes reviewing and correcting it, have been ignored. Likewise any contemporary inscriptions, like pagination or Michaëlis's pencil annotation on folio 1 , have also been disregarded. To facilitate research on literary reception, the data is also grouped under manuscript gathering and poet, as these are crucial details not be found anywhere else.

Even though the manuscript's binding changed over time, the text was edited based on the paper facsimile, which follows the manuscript's state prior to the 1999-2000 restoration. With that sequence in mind, each note is presented in order of appearance and numbered accordingly in the first column. ${ }^{5}$ Henceforth, when referring to a specific item in the table, we will adopt the following convention: CAn., that is, "Cancioneiro da Ajuda note", followed by the relevant number from the first column of the table. ${ }^{6}$

3 Maria Ana Ramos, 'Inuoco el rrey Dom Denis... Pedro Homem e o Cancioneiro da Ajuda', Actes del VII Congrés de l’ Associació Hispànica de Literatura Medieval, 1 (1999), pp. 127-85.

4 Ivo Castro and Maria Ana Ramos, 'Estratégia e táctica da transcrição', Critique textuelle portugaise, Actes du Colloque (1986), 99-122 (p. 112).

5 Text edited based on Cancioneiro da Ajuda: fragmento do nobiliario do conde Dom Pedro: edição fac-similada do códice existente na Biblioteca da Ajuda, ed. by Manuel Cadafaz de Matos (Lisbon: Edições Távola Redonda, 1994).

6 This system was devised by the author as a simple method of referring to the notes, and will be used both in this article and in future. 
The second and third columns of the table give the CA number and incipit to which the notes refer. The fourth column locates each note within the folio. In order to use this information, one should bear in mind that the manuscript's pages have been numbered more than once and that currently more than one pagination system is used in secondary literature. Here we follow the right bottom-page numbering, which runs from folio 1 to 88 . Furthermore, in each manuscript page one finds two columns and it is customary to refer to them as columns $\mathrm{A}$ and $\mathrm{B}$, on the recto side, and $\mathrm{C}$ and $\mathrm{D}$, on the verso. We simplified this system slightly by referring to columns A and B only.

The fifth column of our table provides each note's hand, that is, to whom the note is attributed. This data was collected both from Michaëlis and Pedro and a few contributions have been added, indicated on footnotes. The final column gives the transcription of each note, followed by any relevant remark, again in footnotes.

\section{The Hands}

Hand A, the most prolific - and possibly the oldest - has been described as a fifteenth-century 'gótica cursiva' [gothic cursive]. ' Hand C, the second most frequent, is of a similar type, though 'influenciadas por certas características bastardas' [influenced by certain bastard characteristics]. ${ }^{8}$ Michaëlis dated it from the end of the fifteenth century, though for Pedro it could have been as early as fourteenth or as late as sixteenth century. ${ }^{9}$ More mysterious are a few inscriptions by hand $\mathrm{B}$, so close to the gutter that the text has been trimmed.

Two whole stanzas can be found in the margins. CAn.39, on fol. $33^{\mathrm{r}}$, is by a fourth hand, referred as D, being the latest of all: mid-sixteenth century, according to Michaëlis; late sixteenth or early seventeenth, according to Pedro. ${ }^{10}$ Michaëlis suggested that it could be by the Portuguese poet António Ferreira, whereas Pedro considered it similar to CAn.59, in which case hand D could safely be assumed to be by a man called Gonçalo Gomes Mirador instead. ${ }^{11}$

The second stanza is on fol. 68 and relates to CA 250. Michaëlis oscillated between attributing it to the medieval scribe or to a sixteenth-century hand. ${ }^{12}$ A similar doubt occurred to her when considering the word vacat, on fol. $69^{\mathrm{r}}$, col. B, 1. 11, right, next to CA $253 \mathrm{~b}$, presumably to mark that the cantiga is a

\footnotetext{
7 Susana Tavares Pedro, Análise paleográfica das anotações marginais e finais no Cancioneiro da Ajuda. Paper presented to the Colóquio Cancioneiro da Ajuda (1904-2004), Lisbon, 11-13 November 2004, Faculdade de Letras, Universidade de Lisboa. Available at: <http://www.fcsh.unl.pt/philologia/ Pedro2004_AnalisePaleografica.pdf $>$ [accessed 12 November 2011], p. 18. Michaëlis de Vasconcellos, 1904, II, $176-78, \$ 145,3^{\circ}$.

Pedro, 2004, p. 20; Michaëlis de Vasconcellos, 1904, II, 175-76, \$145, $2^{\circ}$.

9 Michaëlis de Vasconcellos, 1904, II, 175; Pedro, 2004, p. 20.

10 Michaëlis de Vasconcellos, 1904, II, 178, \$145, 4\% ; Pedro, 2004, p. 20.

11 Michaëlis de Vasconcellos, 1904, II, 127.

12 Michaëlis de Vasconcellos, 1904, I, 488; II, 173.
} 
duplicate of CA $248 .{ }^{13}$ Concerning the stanza, Pedro had no doubt in attributing it to a medieval reviser working in the original scriptorium. ${ }^{14}$ As for the note, no opinion is expressed by Pedro, though Ramos considered it to be by the same hand of the stanza, which she called reviser $1 .{ }^{15}$ Therefore, the stanza on fol. 68 is not included in the table, according to the current consensus, although the word vacat is catalogued under CA $n .51$, as there seems to remain some room for doubts about its age.

Michaëlis believed that CAn.44 was by a fifth hand, whereas Ramos associates it with CA $n .58$ and CAn.6o, presumably by a former owner of the manuscript called Pero Homem. ${ }^{16}$ Pedro, instead, attributed it to hand A, an opinion which has been adopted here.

This reduces the dated hands to four, though only two of them, A and C, are both readable and prolific enough to render them useful to our purposes here. Finally, there are certain written vestiges less relevant to the study of the manuscript's reception - property marks, essais de plume and drawings included here more for the sake of comprehensiveness.

One case specifically, however, deserves closer attention, namely CAn.3o, a majuscule $M$, inscribed inside the hat worn by the illuminated picture of a trovador representing Pero Garcia Burgalês, on fol. $21^{r}$. This $M$ has not been counted so far among the marginalia; rather it was hypothesized by Ramos that it stands for Magister, which, combined with the hat, would indicate some special prestige enjoyed by this poet. Although we are inclined to accept her argument concerning the hat, the letter, we would argue, does not stand for Magister. The close similarity, so far unnoticed, between this $M$ and the one on the inscription Dona $M^{a}$, CAn.52, on fol. $70^{\mathrm{r}}$, suggests that they were made by a single reader, situated at a later date, contradicting the idea that the $M$ comes from a scribe working in the original scriptorium.

One may contrast those two to other Ms in the manuscript - for example coloured initial Ms beginning stanzas on fols $4^{\mathrm{v}}$ and $5^{\mathrm{r}}$. The letter type and the overall shape, with curls at the extremes, are all very similar. Yet the side strokes of the Ms on fols $21^{\mathrm{r}}$ and $7 \mathrm{O}^{\mathrm{r}}$ are wide on top and thinner on the bottom, as it approaches the curls. The Ms used as initials are normally wide in the middle and thinner on both top and bottom. The middle stroke in particular is quite distinctive in the marginalia, both being slightly bent.

\footnotetext{
Michaëlis de Vasconcellos, 1904, I, 486; II, 174.

Pedro, 2004, p. 12.

5 Maria Ana Ramos, 'O Cancioneiro da Ajuda: confecção e escrita', 2 vols (unpublished doctoral thesis, Universidade de Lisboa, 2008), available at: <http://repositorio.ul.pt/bitstream/10451/553/1/17066_o_ cancioneiro_1.pdf> [accessed 22 August 2014]), p. 344.

16 Michaëlis de Vasconcellos, 1904, II, 175, \$145, 1º; Ramos, 1999, p. 166.
} 


\section{A Short Analysis of Content}

As the table and the section above outline, there remains doubt when attributing some notes to one of the main hands. Nevertheless, a few observations can be put forward:

- hand $\mathrm{A}$ is present in gatherings one, ten, thirteen and fourteen;

- hand $\mathrm{C}$ in gatherings two, three, four, five, six and eleven;

- apparently, hands $\mathrm{A}$ and $\mathrm{C}$ never occur in the same gathering;

- hand B occurs in isolation (gathering seven), with hand $\mathrm{A}$ (gathering one) and with C (gathering four);

- gathering nine is the only one to bear no inscription or drawing of any kind.

Hands $\mathrm{A}$ and $\mathrm{C}$ are usually abundant in the gatherings in which they appear. It is worth considering why A, writing as many as twenty-three comments in gathering one, for example, would suddenly cease to write on the next, only to return, with a similar intensity, in the tenth. This is particularly significant if we consider point three above. It would appear that these two hands date from a time when the manuscript was not yet bound, that the readers were not reading the gatherings in the sequence we know today and, more disconcertingly, that whatever hand A possessed was not available to $\mathrm{C}$ and vice-versa. Gatherings seven, eight, nine and twelve might constitute yet a third group of gatherings not available to or at least not handled by either hand A or C.

This confirms the palaeographical hypothesis that hands $\mathrm{A}$ and $\mathrm{C}$ are roughly contemporary to one another and suggests that, at this stage, the manuscript was in a considerably dissembled state. Somewhat later, it would appear, is hand B, testifying to a new period for the manuscript, one in which the two or three groups of gatherings are all reassembled. This, however, still pre-dates the binding: hand $\mathrm{B}$ is the one to have written close to the margins which were later trimmed, presumably by the time of its first binding, in the sixteenth century.

If Pedro is right and CAn.44 is indeed by hand $\mathrm{A}$, we can circumscribe these three hands to the period ranging from the second quarter of the fifteenth century, roughly when Juan de Mena was active, up to the sixteenth century, when the manuscript was bound. This partly confirms and partly restricts the dating advanced by Michaëlis based on palaeography, mentioned above. Incidentally, this period overlaps with that covered by Garcia de Resende's Cancioneiro Geral and, since the language employed by these three hands is Portuguese, rather than Castilian, we can say that the marginalia connect the earliest Iberian courtly lyric with late medieval and early modern Portuguese courtly poetry. ${ }^{17}$

It is also worth noting that the Évora folios - the eleven loose folios found around 1840 in the Biblioteca Pública de Évora - do not form any pattern here.

${ }_{17}$ Ramos first advanced this conclusion, though based almost exclusively on CAn.58 and CAn.6o. 
They include folios annotated by hands A, B, C and even non-annotated ones, as the table below reveals:

$\begin{array}{cc}\text { Évora folios } & \text { Marginalia's hand } \\ \text { fol. } 4 \text { (gathering I) } & \mathrm{A} \\ \text { fol. } 16 \text { (gathering III) } & \mathrm{C} \\ \text { fol. } 17 \text { (gathering III) } & \varnothing \\ \text { fol. } 29 \text { (gathering V) } & \varnothing \\ \text { fol. } 36 \text { (gathering VI) } & \varnothing \\ \text { fols } 40-45 \text { (gathering VII) } & \mathrm{B}\end{array}$

This is because these eleven folios were torn out from the manuscript after it was bound, further confirming that the marginalia's period was already over by then. ${ }^{18}$

A final aspect to consider is what hands $\mathrm{A}$ and $\mathrm{C}$ express in terms of literary taste. Michaëlis contrasted marginalia expressing approval, all of which she attributes to $\mathrm{C}$, to those written by $\mathrm{A}$, mainly jocose in tone. Pedro, however, disagrees in some attributions, and she seems to be right. Hand $\mathrm{C}$ is remarkably consistent: it is larger than A, appearing exclusively by the first line of each annotated poem. When in column A of a manuscript page, hand $\mathrm{C}$ can be found close to the majuscule that initiates a poem; in column B, by the end of the first line, that is to say that hand C normally occurs in the inner or outer margins. Therefore, CAn.5 and CAn.19 are clearly not from C: the former is in a small letter, written between columns $\mathrm{A}$ and $\mathrm{B}$, towards the end of the third stanza, whereas the latter, also in a small letter, was written by the fourth line of manuscript. CAn.4, however, casts some doubts.

In total, there are twenty notes expressing approval, including CA $n .1$ and the slightly ambiguous CAn.23 and CAn.43. Of those, fifteen are by hand C, meaning that approval is the single emotion expressed by this hand. Conversely, hand A expresses a full range of emotions: sometimes approving of the poet, at others jesting, it is difficult to determine whether he also expressed disapproval, as he seems to engage in a written dialogue with the poems he comments on. He also included some interjections, carefully marked as 'Latin' the occurrences of the word ergo and gave paraphrases or summaries of a poem's predominant idea, all in a thin letter, close to the text, with no place preference.

The most annotated poet by far is João Soares Somesso, receiving as much as twenty-three comments, mostly by hand A, ranging from irony to approval. Concerning praise, João Soares Somesso, Martim Soares, Airas Carpancho, Rui Queimado, João Garcia de Guilhade, Pai Gomes Charinho and Fernão Velho all received one favourable comment each; Vasco Praga de Sandim, three; Nuno Fernandes Torneol and Pero Garcia Burgalês received five each.

18 We would argue that there can be no doubt that this was the order of events, that is, the binding precedes the plundering of the Évora folios. Michaëlis refers five stubs related to the first five folios and cut stitching where the last six folios were inserted. Vide Michaëlis de Vasconcellos, 1904, II, 136; 148. 
The above list shows no specific pattern. It spans the whole period covered by the Cancioneiro da Ajuda: Sandim and Somesso are among the earliest poets, whereas Charinho is one of the latest. The poems that are praised do not reveal, on the readers' part, any specific preference concerning versification or content. A poem marked by intricate formal features like Martim Soares's CA 45 is not annotated. It is found in gathering two and was presumably accessible to hand C. Yet an equally sophisticated and very similar poem by Burgalês, CA 87 , was considered good by hand C. This same hand approved of CA 104, one out of four poems in which Burgalês plays with the secrecy topos by declaring that his lady has one out of three ordinary names (Joana, Sancha and Maria). Hand C, therefore, was probably aware of the conventions which established that the beloved's name must be kept secret and enjoyed the humorous twist by Burgalês. But the other three poems in this cycle - CA 89, CA 105, CA $106-$ all of which employ the same joke, were ignored.

To say that these expressions of taste are unsystematic does not mean that they are useless, though. They reveal something, fragmentary as it may be, about the literary taste of fifteenth-century Portuguese audiences. Above all, they testify to a special, possibly renewed, interest in Galician-Portuguese lyric, which was regarded both as poetry worthy of private reading and as a possible source for new compositions, as revealed by CAn.44. In the future, it would be worth considering whether the annotated poems can be linked in some way to poems or preferences detected in fifteenth-century lírica palaciana. As for GalicianPortuguese lyric, these marginalia, as well as some rare statements to be found elsewhere - like the Livros de Linhagens and a few rubrics accompanying cantigas - add to the meagre ranks of quasi-contemporary expressions of taste, which may complement studies on Galician-Portuguese aesthetics. 


\section{Appendix: Late medieval and early modern marginalia to the Cancioneiro da Ajuda}

First gathering

- Vasco Praga de Sandim

1. CA 1 Deus, meu Senhor, se vos prouguer

2. CA 2 Senhor fremosa, grand'enveja hei

4. $\mathrm{CA}_{3}$ Senhor fremosa, par Deus, gran razon

5. CA 10 Que sem conselho que vós, mia senhor

6. CA 13 Par Deus, senhor, sei eu mui bem

- João Soares Somesso

7. CA 15 De quant'eu sempre desejei

8. CA 16 Muitas vezes em meu cuidar

9.

10. CA 17 Nom me poss'eu, senhor, salvar

11.

12. CA 18 Agora m'hei eu a partir

13.

14. CA 20 Nom tenh'eu que coitados som

15. CA 21 Punhei eu muit'em me guardar f. ${ }^{r}$, col. A, 1l. 18/19, left

f. $1^{r}$, col. A, 11. 21/22, left

f. $1^{\mathrm{r}}$, col. B, bottom centre

f. 1 , col. A, l. 1

f. $3^{\mathrm{r}}$, col. B, l. 17, left

f. $3^{\mathrm{v}}$, col. B, 1l. 15/16, left

f. 4 , col. A, 11. 5/6, left

f. $4^{\mathrm{v}}$, col. A, 1l. 9/10, left

f. $4^{\mathrm{v}}$, col. A, 11. 21/22, left

f. $4^{\mathrm{v}}$, col. B, 1l. 9/10, right

f. 4 , col. B, 1. 24, right

f. $5^{\mathrm{r}}$, col. A, ll. 14/15, left

f. $5^{\mathrm{r}}$, col. A, bottom

f. $5^{\mathrm{v}}$, col. A, 1. 26, right

f. 5 v , col. B, 1. 9, right $\operatorname{diz} u[\mathrm{er}] d a d e^{1}$

este avia ẽveia aos que via morrer

esta tijnha ssua alma mall pensada ${ }^{2}$

boa

boa

fazia-lhe pesar este ẽ na muito amar

ora pois faze-lho

beber sobre o cheiro

muito pode alla fe

estaa bem satesfeito

bo fe $\left.{ }^{[* *}\right]^{4}$

mas muito

mata-llo

este leixa os feitos 5 a deos

calar

1 Following Michaëlis de Vasconcellos, 1904, I, 6; 1904, II, 76, who glossed it as verdade.

This is the most diplomatic reading, also found in Pedro. Michaëlis de Vasconcellos offers two alternative readings: empensada (1904, I, 8) and empregada (1904, II, 176)

3 Very difficult to determine, though A might be the best hypothesis here. Although it is placed in C's preferred position (outer margin, first line), the $b$-shape and size suggest a different hand. Furthermore, there is not any note consensually attributed to $\mathrm{C}$ in this gathering, which, again, reinforces a preference for hand A. Finally, the $b$-shape is similar to that of note 5 and the general outline to that of note 19, both attributed by Pedro to hand A. However, Michaëlis de Vasconcellos, 1904, II, 176, believed that the three of them were by hand C.

4 Although there are clearly some letters after the $e$, Michaëlis de Vasconcellos, 1904, II, 176 transcribes it as bofe. Pedro, 2004, p.17 suggests bofe ssy.

5 Michaëlis de Vasconcellos, 1904, II, 176 does not attempt to transcribe this word. 
16.

17. CA 22 Já m'eu, senhor, houve sazom

18. CA 23 Se eu a mia senhor ousasse

19. CA 24 Senhor fremosa, fui buscar

20. CA 27 Desejand'eu vós, mia senhor

21. CA 28 Já foi sazom que eu cuidei

22. CA 29 Ben'o faria, se nembrar f. $5^{\mathrm{v}}$, col. B, 1. 20, right

f. $6^{\mathrm{r}}$, col. A, 1l. 14/15, left

f. $6^{\mathrm{r}}$, col. B, 1. 3, right

f. $6^{\mathrm{V}}$, col. A, 1. 1, left

f. $7^{\mathrm{r}}$, col. B, 1. 23, left

f. $7^{\mathrm{v}}$, col. A, 1. 11, left

f. $7^{\mathrm{v}}$, col. B, 1. 15, left
$\mathrm{B} ?^{1} \quad\left[{ }^{* * *}\right]^{2}$

A outro dia te vera

A

A

A

A

mylhor he muito dize-llo logo*

boa

ergo

guar-te e cala-te

latim

\section{Second gathering}

- Martim Soares

23. CA 59 Por Deus, senhor, nom me desamparedes $\quad$ f. $14^{\mathrm{r}}$, col. B, 1l. 17/18, left $\quad \mathrm{C}^{3} \quad$ fjna $^{4}$

\section{Third gathering}

- Airas Carpancho

24. CA 64 Quisera-m'ir - tal conselho prendi

- Nuno Fernandes Torneol

25. CA 70 Ir-vos queredes, mia senhor

26. CA 78 Ai eu! e de mim que será?

27. CA 79 Ai mia senhor! U nom jaz al

f. $16^{\mathrm{r}}$, col. A, l. 1, left

f. $18^{\mathrm{r}}$, col. B, 1. 9, right

f. $19^{\mathrm{v}}$, col. B, l. 1, right

f. $19^{\mathrm{v}}$, col. B, 1. 18, left

C

Muito boa

C muj boa ${ }^{5}$

C [sign] $b o a^{6}$

C [sign] boa

f. $20^{\mathrm{r}}$, col. A, 1. 13, left

f. $20^{\mathrm{r}}$, col. A, 1. 8, right

Difficult to determine the hand, though, based on its place on the margin, size and the $q$-shape, it is clearly not A.

2 Michaëlis de Vasconcellos, 1904, II, 76 considers this as 'ilegível' [illegible] but, on p. 178, states that 'se parece a porquê' [looks like porquê]. Pedro ignores it. There also seems to be a blurred majuscule $m$ two lines above it.

A larger, bolder hand. Could this be C? The position, between two columns, would be unusual, though not unique. Yet, it is consistent with other notes by $\mathrm{C}$ as it is placed right at the first line of the cantiga.

4 That is the interpretation of Michaëlis de Vasconcellos, 1904, I, 124 and 202 who contrasts the hand with the scribe's similar word fiĩda. Pedro is silent about it.

5 Michaëlis de Vasconcellos neglected this note.

6 This, like the next six notes and number 46, have an ornamental mark before and, sometimes, after the text. Michaëlis de Vasconcellos, 1904, I and Carter, 1941 interpreted them as large Cs, abbreviating cantiga, whereas Pedro, 2004, p. 19, more accurately, transcribes them as Xs. 
- Pero Garcia Burgalês

30.

31. CA 86 Senhor, per vós sõo maravilhado

32. CA 87 Ai eu coitad'! e por que vi

33. CA 88 Se eu soubesse, u eu primeiro vi

34. CA 92 Se Deus me valha, mia senhor

35

36. CA 93 Pola verdade que digo, senhor

\section{Fifth gathering}

37. CA 104 Joana, dix'eu, Sancha e Maria

\section{Sixth gathering}

- Rui Queimado

38. CA 129 Nostro Senhor Deus! e por que neguei

39. CA 130 Deste mund'outro bem nom querria

\section{Seventh gathering}

- João Soares Coelho

40. CA 165 Nunca coitas de tantas guisas vi f. $21^{\mathrm{r}}$, col. A, illumination

f. $22^{\mathrm{r}}$, col. A, 1. 17, left

f. $22^{\mathrm{r}}$, col. B, 1. 16, right

f. $22^{\mathrm{v}}$, col. A, 1. 13, left

f. $23^{\mathrm{r}}$, col. B, 1. 22, right

f. $23^{\mathrm{v}}$, col. A, 1l. $5 / 6$, left

f. $23^{\mathrm{v}}$, col. A, l. 26 , left

f. 26 r, col. B, 1. 19, right
$M$

[sign] boa

[sign] boa [sign]

[sign] boa [sign]

boo diz dajã

cartuxo

boa

$\mathrm{C}^{3} \quad$ mujto boa

This is probably the most obscure note, partly because the text was trimmed on the right margin. No consensus has been reached: Michaëlis de Vasconcellos, 1904, II, 178 offers bõo dizer daran; Carter, 1941, p. 55 attempts bõo diz’ da fa and Pedro, 2004, p. 19 suggests $R^{\circ}$ boo diz dasã.

Pedro, 2004, p. 19 does not attempt to attribute it to any hand. Because of the $b$-shape and its position by the majuscule, C is the best guess, following Michaëlis de Vasconcellos, 1904, II, 176.

3 Pedro, 2004, p. 19 has doubts in attributing it to C. Again, because of its position by the first line of the poem, C is the safest hypothesis.

4 It is clearly the same hand of the previous note. Pedro, accordingly, also has doubts in attributing it to C. The position is unusual, by the picture, rather than by the majuscule.

5 Pedro, 2004, pp. 20-21 could not read it either. Michaëlis de Vasconcellos, 1904, I, 263 transcribes as: Outro ben d'este mundo non querria | pol[as] coitas qu' amor me faz sofrer que mia sen[h]or meu mal todo sabia $\mid$ e que soubess' eu sempre atender. Se esse ben ouvesse, averia $\mid$ o mais do ben que ja querri' aver | ella o sabe ben sen lho dizer (riscado e substituido pelo verso seguinte: soubera o ela ben sen lho dizer) | e o sen posera en min como $d$... | nunca lho ous .... dizer. In 1904, II, p.178, an alternative readings by Britto-Rebello is provided: que mia senhor meu mal todo entender | e que soubesse eu bem q̄ o entendia (1l. 3-4); and como dizia | Nunca lhe ... d' alma dizer. (1l. 8-9).

6 This is the reconstruction of another trimmed note by Michaëlis de Vasconcellos, 1904, I, 331. Pedro, 2004, p. 19 gives a slightly different reading. 


\section{Eighth gathering}

41. Blank page

\section{Tenth gathering}

- João Garcia de Guilhade

42. CA 230 Senhor, veedes-me morrer

43. CA 231 U m'eu parti d'u m'eu parti

44. CA 232 A bõa dona por que eu trobava

45

46.

47. CA 233 Amigos, quero-vos dizer - Pai Gomes Charinho

48. CA 246 A dona que home 'senhor' devia f. $47^{\mathrm{v}}$, centre

f. $62^{\mathrm{r}}$, col. B, 1.4 , right

f. $62^{\mathrm{v}}$, col. A, 1. 6, left

f. $62^{\mathrm{v}}$, col. A, 1. 21, left

f. $62^{\mathrm{v}}$, col. B, l. 7, right

f. $62^{\mathrm{v}}$, col. B, 1. 16, right

f. $63^{\mathrm{r}}$, col. A, 1. 7, left

f. $67^{\mathrm{r}}$, col. B, 11. 17/18, right a drawing

\section{Eleventh gathering}

49. CA 250 Coidava-m'eu, quand'amor nom havia

f. $68^{\mathrm{r}}$, col. A, 1. 18 , left

50. CA 252 Senhor fremosa, pois que Deus non quer

51. CA 253b Oí eu sempre, mia senhor, dizer

52. CA 256 De quantas cousas eno mundo son,

f. $68^{\mathrm{v}}$, col. B, bottom

f. $69^{\mathrm{r}}$, col. B, l. 11, right

f. $7 \mathrm{O}^{\mathrm{r}}$, col. B, bottom

1 Following Michaëlis de Vasconcellos, 1904, I, 451. Pedro, 2004, p. 18 reads fino.

2 Pedro, 2004, p. 18: 'Maria Ana Ramos, no estudo em que debate a identificação do "Pêro Homem", provável possuidor do Cancioneiro, sugere que a ele

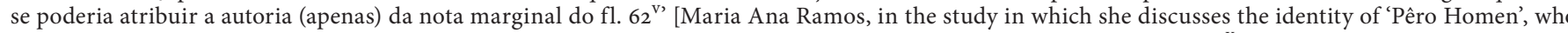
probably owned the Cancioneiro, suggests that we can attribute to him only the authorship of the marginal note on fol. $\left.62^{\mathrm{v}}\right]$. The quotation, however, was not found in Ramos's article. Michaëlis de Vasconcellos, 1904, II, 175 believed that this and note 40 were the only inscriptions by a fifth hand, older than all the others. Pedro, 2004, p. 18, conversely, argues that this is hand A.

3 Michaëlis de Vasconcellos, 1904, I, 453 offers gabar-sse-me quer.

4 Michaëlis de Vasconcellos, 1904, II, 177 final reading is andae era maa $u$ vades. Pedro, 2004, p. 18 sees andae ẽ era maao vades. However, there might be more letters between $m$ and $o$ than either of them believed.

5 Michaëlis de Vasconcellos, 1904, I, 331 gives a partial transcription and believes it to be by hand A. Given the ink colour and position in the margin, this is very unlikely. Pedro attributes it to the reviser.

6 Michaëlis de Vasconcellos, 1904, I, 331 initially dates it from the sixteenth century. Later, in Michaëlis de Vasconcellos, 1904, II, 174, she expresses sheer indecision: 'copista, revedor, leitor ou collacionador'. Ramos, 2008, p. 344 attributes it to reviser 1. Pedro ignores it.

rrespondeo-lhe

fina

trobasses tu ber eno lhe pesara

gabarsse-nos quer

andae ẽ era $\left.m^{[* * *}\right]$ o vades ${ }^{4}$

se a nõ visse $p[. .$.$] perdia o ssem [...] e$ $[* * *][. .$.$] amigos al e dix [\ldots]^{5}$

[sign] Mujto boa

a grotesque

Dona $M^{a}$ 
- Fernão Velho

53. CA 259 Senhor que eu por meu mal vi

54 .

55 .

Twelfth gathering

56. Blank page

Thirteenth gathering

$$
\text { - Pero da Ponte }
$$

57. CA 288 Tam muito vos am'eu, senhor

\section{Fourteenth gathering}

58. Blank page

59.

— Rui Fernandes de Santiago

60

61. CA 309 Ora começa o meu mal

62. Blank page f. $81^{\mathrm{v}}$, col. B, 1. 15, right

$$
\begin{aligned}
& \text { f. } 71^{\mathrm{v}} \text {, col. A, 1. 3, left } \\
& \text { f. } 71^{\mathrm{v}} \text {, col. A, 11. 4/6, left } \\
& \text { f. } 71^{\mathrm{v}} \text {, col. A, 1. } 7 \text {, left }
\end{aligned}
$$

f. $77^{r}$, full page

?

A

f. $86^{\mathrm{V}}$, top

f. $86^{\mathrm{V}}$, centre/left

f. $88^{\mathrm{V}}$, top

f. $88^{\mathrm{V}}$, col. A, ll. $18 / 19$, left

f. $87^{\mathrm{r}}$, full page

\section{C muj mujto boa}

several $y$

a johã de [***]

various drawings and inscriptions

e por este sse dise guardando he que deos guarda

[sign or $E$ ] $p^{\circ} \operatorname{hom}\left[{ }^{*}\right.$ ]

guonçalo guomez mirador guonçalo guomez mirador guonçalo g[***]m

[sign or $E] p^{\circ} \operatorname{hom}\left[^{*}\right]^{1}$

ao demo ao demo o amor

various inscriptions and drawings ${ }^{2}$

Michaëlis de Vasconcellos, 1904, II, 178 offers P. Gomes dasinhaga.

Michaëlis de Vasconcellos, 1904, II, 179 transcribes six fragmentary inscriptions. 